\title{
Highly selective partial dehydrogenation of tetrahydroisoquinolines using modified Pd/C
}

\author{
Yue Ji a, Mu-Wang Chen a, Lei Shi a,b,*, Yong-Gui Zhou ${ }^{\text {a,\# }}$ \\ a Dalian Institute of Chemical Physics, Chinese Academy of Sciences, Dalian 116023, Liaoning, China \\ b State Key Laboratory of Fine Chemicals, Dalian University of Technology, Dalian 116024, Liaoning, China
}

\section{A R T I C L E I N F O}

\section{Article history:}

Received 1 October 2014

Accepted 3 November 2014

Published 20 January 2015

\section{Keywords:}

Palladium on carbon

Partial dehydrogenation

Tetrahydroisoquinoline

Imine

Dehydroaromatization

\begin{abstract}
A B S T R A C T
A highly selective procedure has been developed for the partial dehydrogenation of 1-substituted-1,2,3,4-tetrahydroisoquinolines over $\mathrm{K}_{3} \mathrm{PO}_{4} \cdot 3 \mathrm{H}_{2} \mathrm{O}$-modified $\mathrm{Pd} / \mathrm{C}$ catalyst. This new method provides facile, atom-economical and environmentally friendly access to 1-substituted-3,4-dihydroisoquinolines without the need for stoichiometric amounts of harmful oxidants. The use of standard $\mathrm{Pd} / \mathrm{C}$ as a catalyst for this process gave poor chemoselectivity. Pleasingly, the use of a $\mathrm{K}_{3} \mathrm{PO}_{4} \cdot 3 \mathrm{H}_{2} \mathrm{O}$-modified $\mathrm{Pd} / \mathrm{C}$ catalyst promoted the partial dehydrogenation of 1-substituted-1,2,3,4tetrahydroisoquinolines with excellent chemoselectivity by suppressing further dehydroaromatization. Furthermore, conducting the reaction under an atmosphere of oxygen led to further improvements in the chemoselectivity of the dehydrogenation, with the ratio of imine to isoquinoline reaching up to $32 / 1$. The heterogenous $\mathrm{Pd} / \mathrm{C}$ catalyst could also be recycled and reused at least three times with excellent conversion and chemoselectivity, demonstrating the significantly practical potential of this methodology.
\end{abstract}

(C) 2015, Dalian Institute of Chemical Physics, Chinese Academy of Sciences. Published by Elsevier B.V. All rights reserved.

\section{Introduction}

Imines are one of the most frequently used substrates in synthetic chemistry where they feature strongly in a variety of organic transformations, including cyclization reactions and reactions involving the addition of nucleophiles to the carbon atom of the imine bond. The oxidation of cyclic amines to the corresponding cyclic imines is an important synthetic methodology, which generally requires the addition of a stoichiometric oxidant [1-11], such as iodine, sulfur, tert-butylhydroperoxide or 3,3-dimethyl-1-butene, which can lead to the formation of harmful waste products. Furthermore, reactions involving the oxidation of amines with trichloroisocyanuric acid [12] or tert-butyl hypochlorite [13] always proceed via a two-step process of $N$-chlorination and dehydrochlorination to give the corresponding imines (Scheme 1) The transition-metal catalyzed dehydrogenation of organic compounds represents a powerful, atom-economical and environmentally benign approach for the introduction of unsaturated double bonds, such as $\mathrm{C}=\mathrm{C}$ [14-19], $\mathrm{C}=\mathrm{N}[20-25]$ and $\mathrm{C}=\mathrm{O}$ [26-31] bonds, whilst avoiding the use of stoichiometric amounts of harmful oxidants. The dehydrogenation of $\mathrm{N}$-heterocycles has attracted considerable interest from both academic and industrial research groups during the course of the past two decades. This method is generally used to prepare $N$-heteroaromatic compounds, which are common structural motifs in pharmaceutical and material chemistry [32-47], because it provides rapid access to stable dehydroaromatization products.

\footnotetext{
* Corresponding author. Tel: +86-411-84379220; E-mail: shileichem@dicp.ac.cn

\# Corresponding author. Tel: +86-411-84379220; E-mail: ygzhou@dicp.ac.cn

This work was supported by the National Natural Science Foundation of China (21202162) and the State Key Laboratory of Fine Chemicals (KF1110). DOI: 10.1016/S1872-2067(14)60243-6 | http://www.sciencedirect.com/science/journal/18722067 | Chin. J. Catal., Vol. 36, No. 1, January 2015
} 


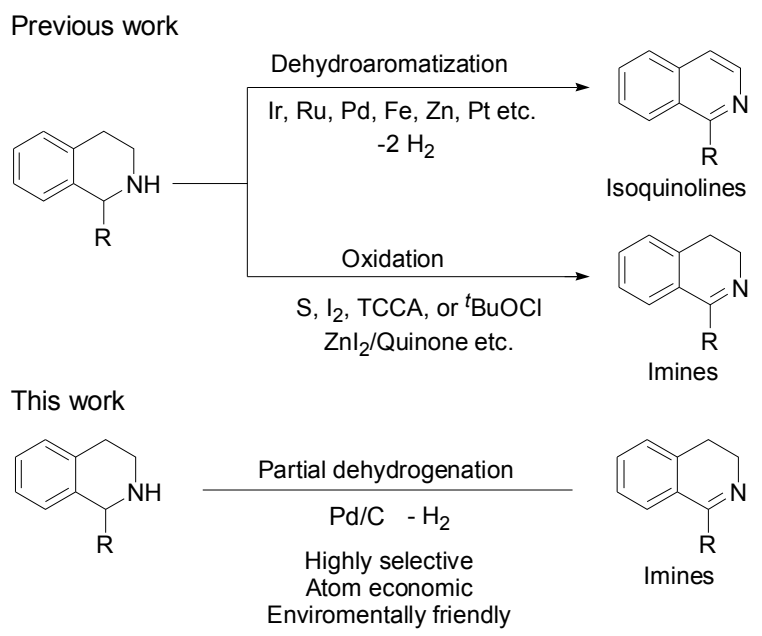

Scheme 1. Metal-catalyzed dehydrogenation of tetrahydroisoquinolines.

Mechanistic studies have shown that the dehydrogenation of $\mathrm{N}$-heterocyclic compounds occurs via a reactive cyclic imine intermediate, followed by further dehydroaromatization $[48,49]$. In theory, cyclic imines could be formed by the controllable dehydrogenation of $\mathrm{N}$-heterocyclic compounds. However, reports pertaining to the development of partial dehydrogenative processes with cyclic imines as products are scarce [50-52]. Stahl's group [50] recently described a Zn/quinone complex catalyzed reaction for the aerobic oxidation of amines to imines with good to excellent yields. Turner's group [51] creatively applied the monoamine oxidase MAO-N D11C as a catalyst for the enantioselective oxidation of amines. It is easy to understand why the dehydrogenation of $\mathrm{N}$-heterocycles is prone to the formation of the final dehydroaromatization products because the resulting aromatic products are much more stable than the corresponding partially oxidized imine intermediates, which are formed as transient species during the dehydrogenative process. The development of new processes capable of achieving high levels of selectivity for the partial dehydrogenation of $\mathrm{N}$-heterocyclic compounds remains a challenging subject in this field of research. A critical issue that needs to be addressed by any new methodology is the suppression of further aromatization, which would lead to significant improvements in the chemoselectivity of dehydrogenation. Given that the different dehydrogenative products of $\mathrm{N}$-heterocyclic compounds, including aromatic compounds and imines, are valuable organic building blocks, the development of an efficient and controllable process for the dehydrogenation of $\mathrm{N}$-heterocyclic compounds is highly desirable. Herein, we report a new $\mathrm{Pd} / \mathrm{C}$-promoted process for the partial dehydrogenation of 1,2,3,4-tetrahydroisoquinolines to 3,4-dihydroisoquinolines exclusively with high levels of activity and chemoselectivity.

\section{Experimental}

\subsection{General methods}

Commercially available reagents and solvents were used without further purification. The $\mathrm{Pd} / \mathrm{C}$ (5\% Pd on carbon) catalyst used in the current study was purchased from J\&K. ${ }^{1} \mathrm{H},{ }^{13} \mathrm{C}$ and ${ }^{19} \mathrm{~F}$ NMR spectra were recorded at room temperature in $\mathrm{CDCl}_{3}$ on a $400 \mathrm{MHz}$ instrument (Brucker) with tetramethylsilane (TMS) as an internal standard. Flash column chromatography was performed on silica gel (200-300 mesh). All of the reactions were monitored by TLC analysis. The 1-substituted-1,2,3,4-tetrahydroisoquinolines were prepared according to the literature methods [53].

\subsection{General procedure for synthesis of imines (2a-l)}

$\mathrm{Pd} / \mathrm{C}\left(254 \mathrm{mg}, 0.12 \mathrm{mmol}\right.$ ) and $\mathrm{K}_{3} \mathrm{PO}_{4} \cdot 3 \mathrm{H}_{2} \mathrm{O}$ (16 mg, 0.06 mmol) were placed in a Schlenk tube followed by acetonitrile (1 $\mathrm{mL}$ ), and the resulting mixture was stirred at room temperature for $10 \mathrm{~min}$. A solution of 1-substituted-1,2,3,4-tetrahydroisoquinoline $(0.30 \mathrm{mmol})$ in acetonitrile $(4 \mathrm{~mL})$ was then added to the reaction mixture, and the Schlenk tube was carefully and quickly vacuum purged before being filled with oxygen using an oxygen balloon. The reaction mixture was then stirred at $60{ }^{\circ} \mathrm{C}$ until the 1-substituted-1,2,3,4-tetrahydroisoquinoline had been completely consumed (as determined by TLC analysis). Upon completion of the reaction, the mixture was slowly cooled to room temperature and filtered through diatomite to remove the $\mathrm{Pd} / \mathrm{C}$ catalyst. The filtrate was then concentrated in vacuo to give the crude product as a residue, which was purified by flash chromatography over silica gel eluting with petroleum ether and ethyl acetate to give the imine product 2.

1-Phenyl-3,4-dihydroisoquinoline (2a): 86\% yield, known compound [54], yellow oil, $R_{\mathrm{f}}=0.75$ (ethyl acetate). ${ }^{1} \mathrm{H}$ NMR (400 MHz, $\left.\mathrm{CDCl}_{3}\right) \delta=7.60-7.56(\mathrm{~m}, 2 \mathrm{H}), 7.44-7.35(\mathrm{~m}, 4 \mathrm{H})$, 7.26-7.21 (m, 3H), 3.85-3.82 (m, 2H), 2.80-2.77 (m, $2 \mathrm{H}) ;{ }^{13} \mathrm{C}$ NMR $\left(100 \mathrm{MHz}, \mathrm{CDCl}_{3}\right) \delta=167.3,139.0,138.9,130.7,129.3$, 128.9, 128.8, 128.1, 127.9, 127.4, 126.6, 47.7, 26.3.

1-Phenylisoquinoline (3a): known compound [55], white solid, $R_{\mathrm{f}}=0.93$ (ethyl acetate), $\mathrm{mp}=73-74{ }^{\circ} \mathrm{C} .{ }^{1} \mathrm{H}$ NMR $(400$ $\left.\mathrm{MHz}, \mathrm{CDCl}_{3}\right) \delta=8.61(\mathrm{~d}, J=5.7 \mathrm{~Hz}, 1 \mathrm{H}), 8.10(\mathrm{~d}, J=8.5 \mathrm{~Hz}, 1 \mathrm{H})$, 7.87 (d, $J=8.2 \mathrm{~Hz}, 1 \mathrm{H}), 7.71-7.63(\mathrm{~m}, 4 \mathrm{H}), 7.55-7.47$ (m, 4H); ${ }^{13} \mathrm{C}$ NMR $\left(100 \mathrm{MHz}, \mathrm{CDCl}_{3}\right) \delta=160.9,142.4,139.8,137.0,130.2$, 130.1, 128.8, 128.5, 127.8, 127.3, 127.2, 126.9, 120.1.

1-(4-Chlorophenyl)-3,4-dihydroisoquinoline (2b): $84 \%$ yield, known compound [54], colorless oil, $R_{\mathrm{f}}=0.50$ (ethyl acetate). ${ }^{1} \mathrm{H}$ NMR (400 MHz, $\left.\mathrm{CDCl}_{3}\right) \delta=7.56-7.40(\mathrm{~m}, 2 \mathrm{H})$, 7.48-7.37 (m, 3H), 7.27-7.21 (m, 3H), 3.85-3.82 (m, 2H), 2.81-2.77 (m, 2H); ${ }^{13} \mathrm{C}$ NMR $\left(100 \mathrm{MHz}, \mathrm{CDCl}_{3}\right) \delta=166.2,138.9$, $137.5,135.4,130.9,130.2,128.5,128.4,127.6,127.5,126.7$, 47.7, 26.3 .

1-(4-Methoxyphenyl)-3,4-dihydroisoquinoline (2c): $89 \%$ yield, known compound [54], colorless oil, $R_{\mathrm{f}}=0.60$ (ethyl acetate). ${ }^{1} \mathrm{H}$ NMR (400 MHz, $\left.\mathrm{CDCl}_{3}\right) \delta=7.57-7.55(\mathrm{~m}, 2 \mathrm{H})$, 7.36-7.23 (m, 4H), 6.95-6.93 (m, 2H), $3.84(\mathrm{~s}, 3 \mathrm{H}), 3.81-3.78$ $(\mathrm{m}, 2 \mathrm{H}), 2.78-2.75(\mathrm{~m}, 2 \mathrm{H}) ;{ }^{13} \mathrm{C}$ NMR $\left(100 \mathrm{MHz} \mathrm{CDCl}_{3}\right) \delta=$ $166.6,160.6,139.1,131.5,130.5,130.3,128.9,127.9,127.4$, 126.5, 113.5, 55.3, 47.5, 26.4.

1-m-Tolyl-3,4-dihydroisoquinoline (2d): 82\% yield, known compound [54], colorless oil, $R_{\mathrm{f}}=0.40$ (petroleum ether $/$ ethyl 
acetate $=2 / 1) .{ }^{1} \mathrm{H}$ NMR $\left(400 \mathrm{MHz}, \mathrm{CDCl}_{3}\right) \delta=7.43(\mathrm{~d}, J=9.1 \mathrm{~Hz}$, $1 \mathrm{H}), 7.41-7.32(\mathrm{~m}, 2 \mathrm{H}), 7.32-7.20(\mathrm{~m}, 5 \mathrm{H}), 3.84$ (dd, $J=8.2,6.4$ $\mathrm{Hz}, 2 \mathrm{H}), 2.83-2.74(\mathrm{~m}, 2 \mathrm{H}), 2.39(\mathrm{~s}, 3 \mathrm{H}) ;{ }^{13} \mathrm{C} \mathrm{NMR}(100 \mathrm{MHz}$, $\left.\mathrm{CDCl}_{3}\right) \delta=167.4,139.0,138.8,137.9,130.6,130.0,129.3,128.9$, $128.0,127.9,127.4,126.6,126.0,47.7,26.4,21.4$.

1-p-Tolyl-3,4-dihydroisoquinoline (2e): $84 \%$ yield, known compound [54], white solid, $R_{\mathrm{f}}=0.45$ (petroleum ether/ethyl acetate $=2 / 1), \mathrm{mp}=73-74{ }^{\circ} \mathrm{C} .{ }^{1} \mathrm{H}$ NMR $\left(400 \mathrm{MHz}, \mathrm{CDCl}_{3}\right) \delta=$ $7.49(\mathrm{~d}, J=8.1 \mathrm{~Hz}, 2 \mathrm{H}), 7.35(\mathrm{td}, J=7.4,1.4 \mathrm{~Hz}, 1 \mathrm{H}), 7.29-7.21$ (m, 5H), 3.84-3.76 (m, 2H), 2.80-2.76 (m, 2H), $2.40(\mathrm{~s}, 3 \mathrm{H}) ;{ }^{13} \mathrm{C}$ NMR $\left(100 \mathrm{MHz}, \mathrm{CDCl}_{3}\right) \delta=167.1,139.2,138.9,136.2,130.5$, 128.9, 128.8, 128.8, 128.0, 127.4, 126.5, 47.6, 26.4, 21.4.

1-(4-(Trifluoromethyl)phenyl)-3,4-dihydroisoquinoline (2f): $82 \%$ yield, known compound [54], pale yellow solid, $R_{\mathrm{f}}=0.60$ (petroleum ether/ethyl acetate $=2 / 1$ ), $\mathrm{mp}=72-74^{\circ} \mathrm{C} .{ }^{1} \mathrm{H}$ NMR $\left(400 \mathrm{MHz}, \mathrm{CDCl}_{3}\right) \delta=7.70(\mathrm{q}, J=8.4 \mathrm{~Hz}, 4 \mathrm{H}), 7.40(\mathrm{td}, J=7.4,1.2$ $\mathrm{Hz}, 1 \mathrm{H}), 7.27$ (dd, $J=16.0,7.4 \mathrm{~Hz}, 2 \mathrm{H}), 7.20(\mathrm{~d}, J=7.4 \mathrm{~Hz}, 1 \mathrm{H})$, 3.90-3.86 (m, 2H), 2.84-2.80 (m, 2H); ${ }^{13} \mathrm{C}$ NMR (100 MHz, $\left.\mathrm{CDCl}_{3}\right) \delta=166.3,142.5,138.7,131.8,131.4,131.1,129.2,128.4$, 127.6, 127.5, 125.2 (q, $J=3.7 \mathrm{~Hz}), 124.1$ (q, $J=271 \mathrm{~Hz}), 47.8$, 26.2; $\left.{ }^{19} \mathrm{~F} \mathrm{NMR} \mathrm{(376} \mathrm{MHz,} \mathrm{CDCl}_{3}\right) \delta-62.66$.

1-(Furan-2-yl)-3,4-dihydroisoquinoline (2g): $88 \%$ yield, known compound [54], yellow oil, $R_{\mathrm{f}}=0.60$ (ethyl acetate). ${ }^{1} \mathrm{H}$ NMR (400 MHz, $\left.\mathrm{CDCl}_{3}\right) \delta=7.71(\mathrm{~d}, J=7.6 \mathrm{~Hz}, 1 \mathrm{H}), 7.58(\mathrm{~d}, J=$ $1.1 \mathrm{~Hz}, 1 \mathrm{H}), 7.40(\mathrm{td}, J=7.4,1.0 \mathrm{~Hz}, 1 \mathrm{H}), 7.32(\mathrm{t}, J=7.2 \mathrm{~Hz}, 1 \mathrm{H})$, $7.26-7.25(\mathrm{~m}, 1 \mathrm{H}), 6.86(\mathrm{~d}, J=3.4 \mathrm{~Hz}, 1 \mathrm{H}), 6.52(\mathrm{dd}, J=3.3,1.7$ $\mathrm{Hz}, 1 \mathrm{H}), 3.83$ (dd, $J=8.1,6.2 \mathrm{~Hz}, 2 \mathrm{H}), 2.76-2.72(\mathrm{~m}, 2 \mathrm{H}) ;{ }^{13} \mathrm{C}$ NMR (100 MHz, $\left.\mathrm{CDCl}_{3}\right) \delta=157.0,151.7,144.0,138.9,130.8$, $127.6,127.5,126.9,126.8,113.1,111.2,47.0,26.2$.

7-Methyl-1-phenyl-3,4-dihydroisoquinoline $\quad$ (2h): $\quad 79 \%$ yield, known compound [56], yellow oil, $R_{\mathrm{f}}=0.50$ (petroleum ether/ethyl acetate $=2 / 1) .{ }^{1} \mathrm{H}$ NMR $\left(400 \mathrm{MHz} \mathrm{CDCl}_{3}\right) \delta=7.59$ $(\mathrm{dt}, J=8.7,3.7 \mathrm{~Hz}, 2 \mathrm{H}), 7.44-7.42(\mathrm{~m}, 3 \mathrm{H}), 7.20-7.15(\mathrm{~m}, 2 \mathrm{H})$, 7.07 (s, 1H), 3.85-3.81 (m, 2H), 2.77-2.74 (m, 2H), 2.29 (s, 3H); ${ }^{13} \mathrm{C}$ NMR $\left(100 \mathrm{MHz}, \mathrm{CDCl}_{3}\right) \delta=167.6,139.4,136.3,136.0,131.5$, $129.4,129.0,128.9,128.6,128.3,127.4,48.1,26.2,21.4$.

7-Chloro-1-phenyl-3,4-dihydroisoquinoline (2i): 76\% yield, known compound [57], white solid, $R_{\mathrm{f}}=0.25$ (petroleum ether/ethyl acetate $=2 / 1), \mathrm{mp}=75-76^{\circ} \mathrm{C} .{ }^{1} \mathrm{H}$ NMR $(400 \mathrm{MHz}$, $\left.\mathrm{CDCl}_{3}\right) \delta=7.59-7.57(\mathrm{~m}, 2 \mathrm{H}), 7.46-7.42(\mathrm{~m}, 3 \mathrm{H}), 7.35$ (dd, $J=$ $7.9,2.1 \mathrm{~Hz}, 1 \mathrm{H}), 7.25(\mathrm{~d}, J=2.1 \mathrm{~Hz}, 1 \mathrm{H}), 7.20$ (d, $J=8.1 \mathrm{~Hz}, 1 \mathrm{H})$, $3.84(\mathrm{dd}, J=8.1,6.4 \mathrm{~Hz}, 2 \mathrm{H}), 2.77-2.74(\mathrm{~m}, 2 \mathrm{H}) ;{ }^{13} \mathrm{C}$ NMR $(100$ $\mathrm{MHz}_{\mathrm{CDCl}}$ ) $\delta=166.2,138.4,137.1,132.3,130.5,130.1,129.6$, $128.7,128.7,128.4,127.8,47.6,25.7$.

7-Methoxy-1-phenyl-3,4-dihydroisoquinoline (2j): $\quad 74 \%$ yield, known compound [58], colorless oil, $R_{\mathrm{f}}=0.74$ (ethyl acetate). ${ }^{1} \mathrm{H}$ NMR $\left(400 \mathrm{MHz}, \mathrm{CDCl}_{3}\right) \delta=7.60$ (dd, $J=6.5,3.2 \mathrm{~Hz}$, $2 \mathrm{H}), 7.43-7.41(\mathrm{~m}, 3 \mathrm{H}), 7.18(\mathrm{~d}, J=8.2 \mathrm{~Hz}, 1 \mathrm{H}), 6.93$ (dd, $J=8.2$, $2.7 \mathrm{~Hz}, 1 \mathrm{H}), 6.82$ (d, $J=2.6 \mathrm{~Hz}, 1 \mathrm{H}), 3.84-3.81(\mathrm{~m}, 2 \mathrm{H}), 3.71$ (s, $3 \mathrm{H}), 2.74-2.70(\mathrm{~m}, 2 \mathrm{H}) ;{ }^{13} \mathrm{C} \mathrm{NMR}\left(100 \mathrm{MHz}^{\left.-\mathrm{CDCl}_{3}\right)} \delta=167.2\right.$, $158.2,138.9,130.9,129.5,129.3,128.8,128.2,128.2,116.1$, $113.8,55.5,48.1,25.5$.

7-Methoxy-1-phenylisoquinoline (3j): 10\% yield, known compound [55], yellow oil, $R_{\mathrm{f}}=0.88$ (ethyl acetate). ${ }^{1} \mathrm{H}$ NMR $\left(400 \mathrm{MHz}^{\mathrm{CDCl}} 3\right) \delta=8.51(\mathrm{~d}, J=5.6 \mathrm{~Hz}, 1 \mathrm{H}), 7.79(\mathrm{~d}, J=8.9 \mathrm{~Hz}$, $1 \mathrm{H}), 7.73-7.71(\mathrm{~m}, 2 \mathrm{H}), 7.54(\mathrm{~m}, 4 \mathrm{H}), 7.39-7.34(\mathrm{~m}, 2 \mathrm{H}), 3.81$ (s, 3H); ${ }^{13} \mathrm{C}$ NMR $\left(100 \mathrm{MHz}, \mathrm{CDCl}_{3}\right) \delta=159.2,158.6,140.6$,
$140.5,139.9,132.5,129.6,128.6,128.5,128.4,127.8,122.9$, $119.7,105.3,55.4$.

6,7-Dimethoxy-1-phenyl-3,4-dihydroisoquinoline (2k): $84 \%$ yield, known compound [54], pale yellow solid, $R_{\mathrm{f}}=0.60$ (dichloromethane $/$ methanol $=15 / 1), \mathrm{mp}=110-112{ }^{\circ} \mathrm{C} .{ }^{1} \mathrm{H}$ NMR (400 MHz, $\left.\mathrm{CDCl}_{3}\right) \delta=7.60(\mathrm{dd}, J=6.3,3.0 \mathrm{~Hz}, 2 \mathrm{H})$, 7.47-7.36 (m, 3H), 6.80-6.77 (m, 2H), $3.94(\mathrm{~d}, J=3.1 \mathrm{~Hz}, 3 \mathrm{H})$, 3.83-3.78 (m, 2H), 3.72 (d, $J=2.7 \mathrm{~Hz}, 3 \mathrm{H}$ ), 2.72 (dd, $J=10.3,4.3$ $\mathrm{Hz}, 2 \mathrm{H}) ;{ }^{13} \mathrm{C}$ NMR (100 MHz, $\left.\mathrm{CDCl}_{3}\right) \delta=166.7,151.0,147.1$, 139.2, 132.6, 129.3, 128.8, 128.1, 121.6, 111.7, 110.3, 56.2, 56.0, 47.7, 26.0 .

6,7-Dimethoxy-1-phenylisoquinoline (3k): 7\% yield, known compound [55], colorless oil, $R_{\mathrm{f}}=0.82$ (dichloromethane/ methanol $=15 / 1) .{ }^{1} \mathrm{H}$ NMR $\left(400 \mathrm{MHz}, \mathrm{CDCl}_{3}\right) \delta=8.48(\mathrm{~d}, J=5.6$ $\mathrm{Hz}, 1 \mathrm{H}), 7.71$ (dd, J = 8.1, 1.3 Hz, 2H), 7.55-7.47 (m, 4H), 7.37 (s, 1H), 7.12 (s, 1H), $4.04(\mathrm{~s}, 3 \mathrm{H}), 3.86(\mathrm{~s}, 3 \mathrm{H}) ;{ }^{13} \mathrm{C} \mathrm{NMR}(100 \mathrm{MHz}$, $\left.\mathrm{CDCl}_{3}\right) \delta=158.3,152.7,150.1,150.1,141.4,140.1,133.8,129.6$, $128.4,122.6,118.7,105.7,105.0,56.1,55.9$.

1-Cyclohexyl-3,4-dihydroisoquinoline (2l): $51 \%$ yield, known compound [54], yellow oil, $R_{\mathrm{f}}=0.70$ (ethyl acetate). ${ }^{1} \mathrm{H}$ NMR (400 MHz, $\left.\mathrm{CDCl}_{3}\right) \delta=7.53-7.50(\mathrm{~m}, 1 \mathrm{H}), 7.33-7.20(\mathrm{~m}$, 2H), 7.29-7.18 (m, 1H), 3.68-3.64 (m, 2H), 2.90 (dd, $J=15.1$, $6.7 \mathrm{~Hz}, 1 \mathrm{H}), 2.67-2.63(\mathrm{~m}, 2 \mathrm{H}), 1.91-1.85(\mathrm{~m}, 4 \mathrm{H}), 1.83(\mathrm{~d}, J=$ $12.3 \mathrm{~Hz}, 1 \mathrm{H}), 1.76-1.24(\mathrm{~m}, 5 \mathrm{H}) ;{ }^{13} \mathrm{C}$ NMR $\left(100 \mathrm{MHz}, \mathrm{CDCl}_{3}\right) \delta=$ 170.8, 138.3, 130.1, 128.9, 127.6, 126.8, 124.6, 46.8, 42.1, 31.3, 26.6, 26.4, 26.3.

1-Cyclohexylisoquinoline (3l): 10\% yield, known compound [39], yellow oil, $R_{\mathrm{f}}=0.82$ (ethyl acetate). ${ }^{1} \mathrm{H}$ NMR $(400 \mathrm{MHz}$, $\left.\mathrm{CDCl}_{3}\right) \delta=8.48(\mathrm{~d}, J=5.7 \mathrm{~Hz}, 1 \mathrm{H}), 8.23(\mathrm{~d}, J=8.4 \mathrm{~Hz}, 1 \mathrm{H}), 7.81$ (d, $J=8.0 \mathrm{~Hz}, 1 \mathrm{H}), 7.67-7.56(\mathrm{~m}, 2 \mathrm{H}), 7.48(\mathrm{~d}, J=5.6 \mathrm{~Hz}, 1 \mathrm{H})$, $3.57(\mathrm{tt}, J=11.7,3.2 \mathrm{~Hz}, 1 \mathrm{H}), 2.01-1.82(\mathrm{~m}, 7 \mathrm{H}), 1.58-1.50(\mathrm{~m}$, $2 \mathrm{H}), 1.45-1.33(\mathrm{~m}, 1 \mathrm{H}) ;{ }^{13} \mathrm{C}$ NMR $\left(100 \mathrm{MHz}, \mathrm{CDCl}_{3}\right) \delta=165.9$, 142.1, 136.6, 129.7, 127.7, 127.0, 126.5, 124.9, 119.0, 41.7, 32.8, 27.1, 26.4 .

1-Cyclohexylidene-1,2,3,4-tetrahydroisoquinoline (41): 27\% yield, unknown compound, yellow oil, $R_{\mathrm{f}}=0.95$ (ethyl acetate). ${ }^{1} \mathrm{H} \mathrm{NMR}\left(400 \mathrm{MHz}, \mathrm{CDCl}_{3}\right) \delta=7.86(\mathrm{~d}, J=7.8 \mathrm{~Hz}, 1 \mathrm{H}), 7.37-7.28$ (m, 2H), 7.24 (d, $J=7.3 \mathrm{~Hz}, 1 \mathrm{H}), 5.70$ (brs, 1H), 3.72-3.68 (m, $2 \mathrm{H}), 2.70-2.66(\mathrm{~m}, 2 \mathrm{H}), 2.14(\mathrm{td}, J=13.1,4.2 \mathrm{~Hz}, 2 \mathrm{H}), 1.93-1.79$ (m, 3H), 1.69-1.66 (m, 2H), 1.56 (d, $J=13.1 \mathrm{~Hz}, 2 \mathrm{H}), 1.45-1.30$ $(\mathrm{m}, 1 \mathrm{H}) ;{ }^{13} \mathrm{C}$ NMR $\left(100 \mathrm{MHz}, \mathrm{CDCl}_{3}\right) \delta=171.0,139.4,130.4$, 128.1, 126.9, 126.6, 126.4, 73.9, 45.8, 36.7, 27.1, 25.6, 22.2. HRMS: $m / z[\mathrm{M}+\mathrm{H}]^{+}$calcd for $\mathrm{C}_{15} \mathrm{H}_{20} \mathrm{~N}=214.1590$; found $=$ 214.1586 .

\subsection{Recycling of $\mathrm{Pd} / \mathrm{C}$ in the dehydrogenation of 1-phenyl-1,2,3,4-tetrahydroisoquinoline}

$\mathrm{Pd} / \mathrm{C}$ (254 mg, $0.12 \mathrm{mmol}$ ) and $\mathrm{K}_{3} \mathrm{PO}_{4} \cdot 3 \mathrm{H}_{2} \mathrm{O}$ (16.0 mg, 0.06 $\mathrm{mmol}$ ) were placed in a Schlenk tube followed by acetonitrile $(1 \mathrm{~mL})$, and the resulting mixture was stirred at room temperature for $10 \mathrm{~min}$. 1-Phenyl-1,2,3,4-tetrahydroisoquinoline (63 $\mathrm{mg}, 0.30 \mathrm{mmol}$ ) and acetonitrile ( $3 \mathrm{~mL}$ ) were then added to the Schlenk tube, and the resulting mixture was carefully and quickly vacuum purged before being filled with oxygen using a balloon. The resulting mixture was then stirred at $60{ }^{\circ} \mathrm{C}$ for 18 h. TLC analysis revealed the complete consumption of 1-phe- 
nyl-1,2,3,4-tetrahydroisoquinoline and the mixture was slowly cooled to room temperature before being filtered through a membrane filter to remove the catalyst. The filtrate was then concentrated in vacuo to give the crude product. ${ }^{1} \mathrm{H}$ NMR analysis of the crude material revealed that it consisted of a 35/1 mixture of $\mathbf{2 a / 3}$. The crude product was purified by flash chromatography over silica gel eluting with a $5 / 1(\mathrm{~V} / \mathrm{V})$ mixture of petroleum ether/ethyl acetate to give the corresponding product imine $2 \mathbf{a}$ in $79 \%$ yield.

The $\mathrm{Pd} / \mathrm{C}$ catalyst recovered from the experiment described above was placed in a Schlenk tube containing $\mathrm{K}_{3} \mathrm{PO}_{4} \cdot 3 \mathrm{H}_{2} \mathrm{O}$ (16.0 $\mathrm{mg}, 0.06 \mathrm{mmol}$ ) and acetonitrile $(1 \mathrm{~mL})$, and the resulting mixture was stirred for $10 \mathrm{~min}$. 1-Phenyl-1,2,3,4-tetrahydroisoquinoline ( $63 \mathrm{mg}, 0.30 \mathrm{mmol}$ ) and acetonitrile $(3 \mathrm{~mL})$ were then added to the reaction, and the resulting mixture was stirred at $60^{\circ} \mathrm{C}$ for $42 \mathrm{~h}$ to allow for the complete consumption of the starting materials (as determined by TLC). The reaction mixture was then worked up according to the procedure described above to give the crude product, which was found to consist of a $44 / 1$ mixture of $\mathbf{2 a} / \mathbf{3 a}$ by ${ }^{1} \mathrm{H}$ NMR analysis. The crude product was then purified by flash chromatography over silica gel eluting with a 5/1 mixture of petroleum ether/ethyl acetate to give the corresponding product imine 2a in $80 \%$ yield.

The Pd/C catalyst used above was recovered and used for a third time according to the same procedure, except the reaction required $96 \mathrm{~h}$ at $60{ }^{\circ} \mathrm{C}$ to reach completion. ${ }^{1} \mathrm{H}$ NMR analysis of the crude product revealed that it consisted of a mixture of $\mathbf{2 a} / \mathbf{3 a}=42 / 1$. The crude product was then purified by flash chromatography over silica gel eluting with a mixture of petroleum ether/ethyl acetate $(V / V)=5 / 1$ to give the corresponding product imine $2 \mathrm{a}$ in $87 \%$ yield.

\section{Results and discussion}

Compound 1a was selected as a model substrate to explore the partial dehydrogenation of 1-substitued-1,2,3,4-tetrahydroisoquinolines using $\mathrm{Pd} / \mathrm{C}$ as the catalyst. Several solvents were screened in the reaction, including DCM, MeOH, THF, toluene and acetonitrile (Table 1, entries 1-5). Acetonitrile was found to be the best solvent for the reaction, giving a $62 \%$ conversion of the starting material. The reaction was also found to be sensitive to temperature (Table 1, entries 5-8). Increasing the temperature led to an increase in the rate of the reaction, but also led to an increase in the amount of the aromatization product. When the reaction was conducted at $80^{\circ} \mathrm{C}$, the ratio of imine to isoquinoline decreased significantly to $6 / 1$. This result therefore confirmed that a temperature of $60^{\circ} \mathrm{C}$ was optimum for this transformation in terms of the reactivity and chemoselectivity. It is well known that the catalytic property of heterogeneous catalysts can be modified by the introduction of an additive, such as the modification of Lindlar's catalyst with a P2-nickel catalyst additive. Li's group [59] recently developed an alkaline salt-modified supported Pd catalyst for the selective racemization and dynamic kinetic resolution of primary amines. Inspired by this work, we investigated the effect of adding different bases to the $\mathrm{Pd} / \mathrm{C}$ catalyst used in the current
Table 1

Evaluation of the reaction parameters.

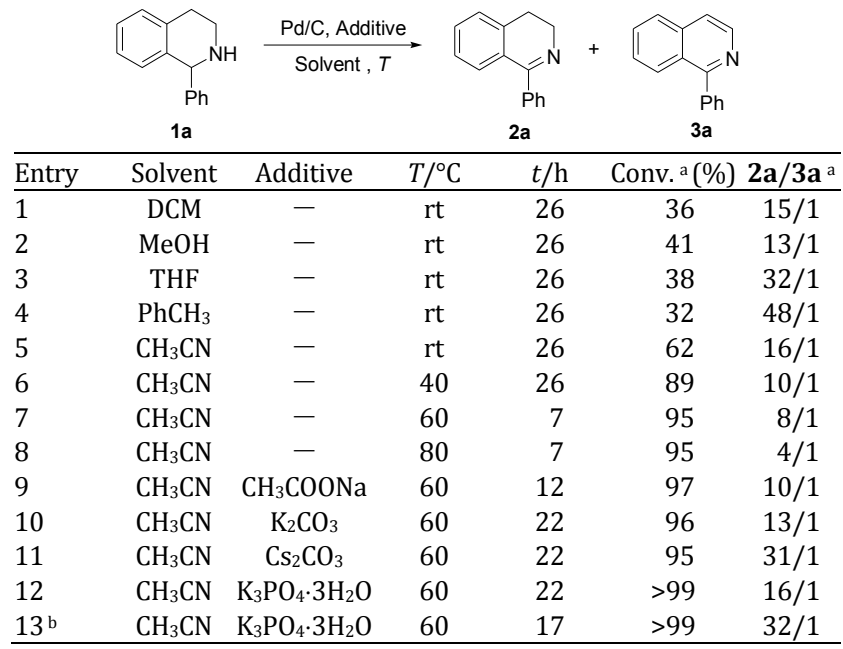

Conditions: 1a $(0.125 \mathrm{mmol}), \mathrm{Pd} / \mathrm{C}(0.050 \mathrm{mmol})$ and $\mathrm{K}_{3} \mathrm{PO}_{4} \cdot 3 \mathrm{H}_{2} \mathrm{O}$ $(0.025 \mathrm{mmol})$ in solvent $(3 \mathrm{~mL})$.

${ }^{\text {a }}$ Determined by ${ }^{1} \mathrm{H}$ NMR analysis of the crude products.

${ }^{\mathrm{b}} \mathrm{O}_{2}$ balloon.

transformation (Table 1, entries 9-13). As expected, the addition of a base led to an increase in the chemoselectivity of the reaction. The use of weakly basic $\mathrm{CH}_{3} \mathrm{COONa}$ as an additive led to an increase in the chemoselectivity of $\mathbf{2 a / 3 a}$ from $8 / 1$ to $10 / 1$. Pleasingly, the use of stronger inorganic bases such as $\mathrm{K}_{2} \mathrm{CO}_{3}$ and $\mathrm{Cs}_{2} \mathrm{CO}_{3}$ led to greater increases in the chemoselectivity of $\mathbf{2 a} / \mathbf{3 a}=13 / 1$ and $31 / 1$, respectively (Table 1 , entries 10-11). Interestingly, the addition of $\mathrm{K}_{3} \mathrm{PO}_{4} \cdot 3 \mathrm{H}_{2} \mathrm{O}$ to the $\mathrm{Pd} / \mathrm{C}$ catalyst gave excellent activity and good selectivity (Table 1 , entry 12). Furthermore, the use of $\mathrm{K}_{3} \mathrm{PO}_{4} \cdot 3 \mathrm{H}_{2} \mathrm{O}$ under an oxygen atmosphere led to a significant increase in the chemoselectivity from $16 / 1$ to $32 / 1$ (Table 1, entry 13). However, the effect of oxygen on the selectivity of the dehydrogenation reaction remains unclear. Taken together, these experiments revealed that the optimum conditions for the reaction were $\mathrm{Pd} / \mathrm{C}$ $(0.12 \mathrm{mmol})$ and $\mathrm{K}_{3} \mathrm{PO}_{4} \cdot 3 \mathrm{H}_{2} \mathrm{O}(0.06 \mathrm{mmol})$ in acetonitrile at 60 ${ }^{\circ} \mathrm{C}$ under an atmosphere of $\mathrm{O}_{2}$ (balloon).

With the optimal conditions in hand, we proceeded to explore the scope of this transformation using a range of 1-substituted-1,2,3,4-tetrahydroisoquinolines $\mathbf{1}$, and the results are summarized in Table 2. The results showed that almost all of the 1-aryl substituted substrates tested in the current study reacted smoothly to afford the desired products in good to excellent yields, regardless of the electronic properties of the $\mathrm{C} 1$ substituent of the aromatic ring (Table 2, entries 1-11). Although the corresponding isoquinoline products were also formed in each of these reactions, the ratio of $2 / 3$ was greater than 20/1 in most cases. It is noteworthy that 6,7-dimethoxy-1phenyl-1,2,3,4-tetrahydroisoquinoline (1k) gave the corresponding product in $84 \%$ yield with a lower catalyst loading of $0.06 \mathrm{mmol} \mathrm{Pd} / \mathrm{C}$ (Table 2, entry 11).

Furthermore, 1-cyclohexyl-1,2,3,4-tetrahydroisoquinoline (11) was quantitatively converted to three different dehydrogenative products (2l, 31 and $\mathbf{4 l}$ ) under the optimized conditions, with the desired partial dehydrogenative product $2 \mathbf{l}$ be- 
Table 2

Selective dehydrogenation of tetrahydroisoquinoline derivatives.

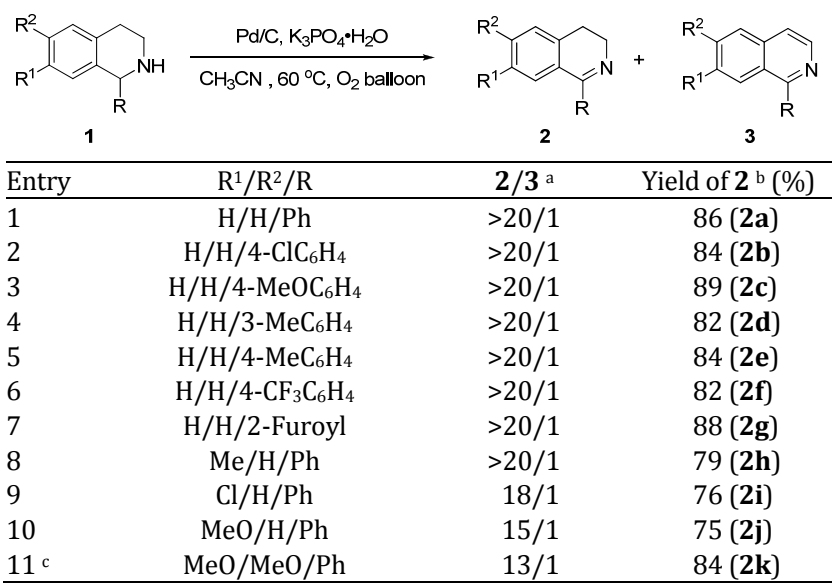

Conditions: $1(0.30 \mathrm{mmol}), \mathrm{Pd} / \mathrm{C}(0.12 \mathrm{mmol})$ and $\mathrm{K}_{3} \mathrm{PO}_{4} \cdot 3 \mathrm{H}_{2} \mathrm{O}(0.06$ $\mathrm{mmol})$ in $\mathrm{CH}_{3} \mathrm{CN}(4 \mathrm{~mL})$ at $60^{\circ} \mathrm{C}$ for $10-22 \mathrm{~h}$.

a Determined by ${ }^{1} \mathrm{H}$ NMR analysis of the crude products.

$\mathrm{b}$ Isolated yields.

c $0.06 \mathrm{mmol} \mathrm{Pd} / \mathrm{C}$.

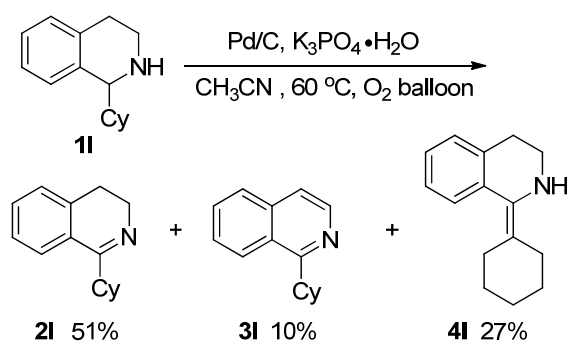

Scheme 2. Dehydrogenation of 1-cyclohexyl-1,2,3,4-tetrahydroisoquinoline.

ing formed in 51\% yield. The unwanted dehydrogenative products 1-cyclohexylisoquinoline (31) and 1-cyclohexylidene1,2,3,4-tetrahydroisoquinoline (4l) were formed in $10 \%$ and $27 \%$ yields, respectively (Scheme 2 ).

The recyclability of this $\mathrm{K}_{3} \mathrm{PO}_{4}$-modified $\mathrm{Pd} / \mathrm{C}$ catalyst was also explored (Table 3). The dehydrogenation of 1-phenyl1,2,3,4-tetrahydroisoquinoline (1a) was performed under the standard reaction conditions. Upon completion of the reaction (as determined by TLC analysis), the solvent was removed by membrane-filtration and the catalyst was recovered and reused in the next reaction. Although there was a small decrease in the

Table 3

Recyclability of the Pd/C catalyst.

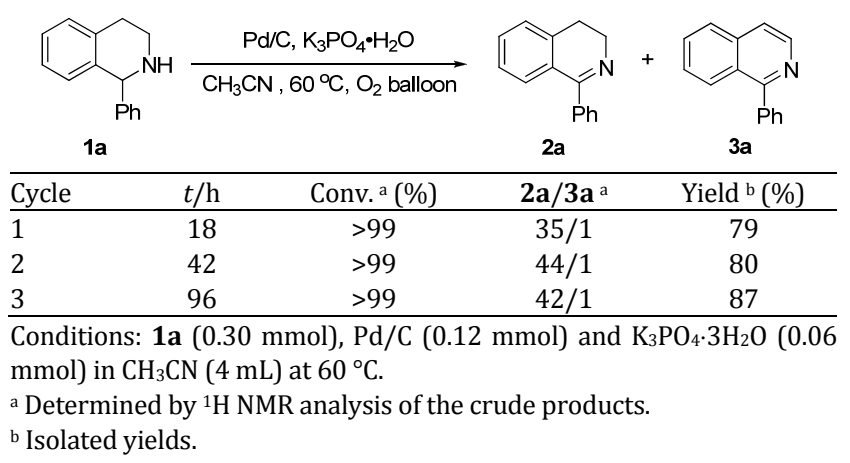

activity of the recovered catalyst, the reaction could be pushed to completion by extending the reaction time. Pleasingly, the recovered catalyst afforded excellent chemoselectivity after the third cycle. This result therefore demonstrates the potential of this newly developed $\mathrm{K}_{3} \mathrm{PO}_{4}$-modified $\mathrm{Pd} / \mathrm{C}$ catalyst as a highly practical system for the dehydrogenation of tetrahydroisoquinolines.

\section{Conclusions}

We have described the development of a highly selective process for the partial dehydrogenation of 1-substituted1,2,3,4-tetrahydroisoquinolines using modified Pd/C. This new process provides an atom-economical and environmentally friendly method for the preparation of 1-substituted-3,4-dihydroisoquinolines without using stoichiometric amounts of harmful oxidants. The key feature of this reaction is the addition of $\mathrm{K}_{3} \mathrm{PO}_{4} \cdot 3 \mathrm{H}_{2} \mathrm{O}$ to modify the $\mathrm{Pd} / \mathrm{C}$ catalyst, which dramatically improves the chemoselectivity by suppressing the reaction of the desired product to give aromatic products. Further research into the use of this catalytic system to prepare simple acyclic imines and its application in cascade reactions is currently underway in our laboratory.

\section{References}

[1] Orito K, Hatakeyama T, Takeo M, Uchiito S, Tokuda M, Suginome H. Tetrahedron, 1998, 54: 8403

[2] Ajzert K I, Takács K. Liebigs Ann Chem, 1987: 1061

[3] Khatri P K, Jain S L, Sivakumar K L N, Sain B. Org Biomol Chem, 2011, 9: 3370

[4] Yao W B, Zhang Y X, Jia X Q, Huang Z. Angew Chem Int Ed, 2014, 53: 1390

[5] Choi H, Doyle M P. Chem Commun, 2007: 745

[6] Goti A, Romani M. Tetrahedron Lett, 1994, 35: 6567

[7] Kamal A, Devaiah V, Reddy K L, Shankaraiah N. Adv Synth Catal, 2006, 348: 249

[8] Chen Y, Crockett R D, Wang X, Larsen R D, Cui S, Faul M M. Synlett, 2013, 24: 301

[9] Aoyama T, Sonoda N, Yamauchi M, Toriyama K, Anzai M, Ando A, Shioiri T. Synlett, 1998, 1: 35

[10] Huang B, Tian H W, Lin S S, Xie M H, Yu X C, Xu Q. Tetrahedron Lett, 2013, 54: 2861

[11] Reyes-Sánchez A, Cañavera-Buelvas F, Barrios-Francisco R, Cifuentes-Vaca O L, Flores-Alamo M, García J J. Organometallics, 2011, 30: 3340

[12] Bolchi C, Pallavicini M, Fumagalli L, Straniero V, Valoti E. Org Process Res Dev, 2013, 17: 432

[13] Scully F E Jr, Schlager J J. Heterocycles, 1982, 19: 653

[14] Choi J, MacArthur A H R, Brookhart M, Goldman A S. Chem Rev, 2011, 111: 1761

[15] Esswein A J, Nocera D G. Chem Rev, 2007, 107: 4022

[16] Zhang W, Ma H, Zhou L P, Miao H, Xu J. Chin J Catal (张伟, 马红, 周 利鹏, 苗虹, 徐杰. 催化学报), 2009, 30:86

[17] Li C G, Miao C X, Nie Y Y, Yue Y H, Gu S Y, Yang W M, Hua W M, Gao Z. Chin J Catal (李春光, 缪长喜, 聂颖颖, 乐英红, 顾松园, 杨为民, 华伟明, 高滋. 催化学报), 2010, 31: 993

[18] Ye X N, Hua W M, Yue Y H, Miao C X, Xie Z K, Gao Z. Chin J Catal (叶 兴南, 华伟明, 乐英红, 缪长喜, 谢在库, 高滋. 催化学报), 2004, 25: 581 


\title{
Graphical Abstract
}

Chin. J. Catal., 2015, 36: 33-39 doi: 10.1016/S1872-2067(14)60243-6

\section{Highly selective partial dehydrogenation of tetrahydroisoquinolines using modified Pd/C}

Yue Ji, Mu-Wang Chen, Lei Shi*, Yong-Gui Zhou*

Dalian Institute of Chemical Physics, Chinese Academy of Sciences; Dalian University of Technology

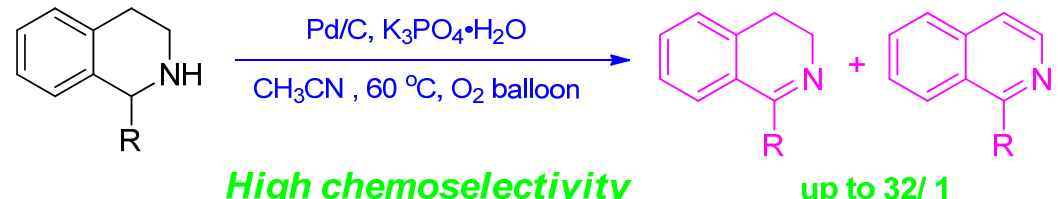

A highly selective reaction has been developed for the partial dehydrogenation of 1-substituted-1,2,3,4-tetrahydroisoquinolines using a $\mathrm{K}_{3} \mathrm{PO}_{4} \cdot 3 \mathrm{H}_{2} \mathrm{O}$-modified $\mathrm{Pd} / \mathrm{C}$ catalyst, which can be readily recycled and reused. This reaction provides facile and atom-economical access to 1-substituted-3,4-dihydroisoquinolines with excellent chemoselectivity by suppressing further dehydroaromatization.

[19] Jin M, Cheng Z M, Jiang X X, Gao Y L, Fang X C. Chin J Catal (晋梅, 程振民，江晓霞，高玉兰，方向晨. 催化学报), 2010,31: 1177

[20] Dobereiner G E, Crabtree R H. Chem Rev, 2010, 110: 681

[21] Schümperli M T, Hammond C, Hermans I. ACS Catal, 2012, 2: 1108

[22] Largeron M. EurJ Org Chem, 2013: 5225

[23] Patil R D, Adimurthy S. Asian J Org Chem, 2013, 2: 726

[24] Angelici R J. Catal Sci Technol, 2013, 3: 279

[25] Turner N J. Chem Rev, 2011, 111: 4073

[26] Li Z C, Chen C H, Zhan E S, Ta N, Shen W J. Catal Commun, 2014, 51: 58

[27] Li Z C, Chen C H, Zhan E S, Ta N, Li Y, Shen W J. Chem Commun, 2014, 50: 4469

[28] Li Z C, Li Y, Zhan E S, Ta N, Shen W J. J Mater Chem A, 2013, 1: 15370

[29] Shi Q J, Liu N, Liang Y. Chin J Catal (石秋杰, 刘宁, 梁义. 催化学 报), 2007, 28: 57

[30] Chen J, Zhang Q H, Fang W H, Wang Y, Wan H L. Chin J Catal (陈静, 张庆红, 方文浩, 王野, 万惠霖. 催化学报), 2010,31: 1061

[31] Wang F, Shi R J, Liu Z Q, Shang P J, Pang X Y, Shen S, Feng Z C, Li C, Shen W J. ACS Catal, 2013, 3: 890

[32] Adkins H, Lundsted L G. J Am Chem Soc, 1949, 71: 2964

[33] Angelici R J.J Organomet Chem, 2008, 693: 847

[34] Jin X K, Liu Y X, Lu Q Q, Yang D Y, Sun J K, Qin S S, Zhang J W, Shen J X, Chu C H, Liu R H. Org Biomol Chem, 2013, 11: 3776

[35] Gu X Q, Chen W, Morales-Morales D, Jensen C M. J Mol Catal A, 2002, 189: 119

[36] Lu S M, Wang Y Q Han X W, Zhou Y G. Chin J Catal (卢胜梅, 汪游 清, 韩秀文, 周永贵. 催化学报), 2005, 26: 287

[37] Wang D W, Wang X B, Wang D S, Lu S M, Zhou Y G, Li Y X. J Org Chem, 2009, 74: 2780

[38] Yamaguchi R, Ikeda C, Takahashi Y, Fujita K I. J Am Chem Soc, 2009, 131: 8410

[39] Wu J J, Talwar D, Johnston S, Yan M, Xiao J L. Angew Chem Int Ed,
2013, 52: 6983

[40] Fujita K I, Tanaka Y, Kobayashi M, Yamaguchi R. J Am Chem Soc, 2014, 136: 4829

[41] Yi C S, Lee D W. Organometallics, 2009, 28: 947

[42] Wendlandt A E, Stahl S S. J Am Chem Soc, 2014, 136: 11910

[43] Hara T, Mori K, Mizugaki T, Ebitani K, Kaneda K. Tetrahedron Lett, 2003, 44: 6207

[44] Dean D, Davis B, Jessop P G. New J Chem, 2011, 35: 417

[45] Chakraborty S, Brennessel W W, Jones W D. J Am Chem Soc, 2014, 136: 8564

[46] Luca O R, Huang D L, Takase M K, Crabtree R H. New J Chem, 2013, 37: 3402

[47] Zhang D, Wu L Z, Zhou L, Han X, Yang Q Z, Zhang L P, Tung C H. J Am Chem Soc, 2004, 126: 3440

[48] Li H, Jiang J, Lu G, Huang F, Wang Z X. Organometallics, 2011, 30: 3131

[49] Zhang X B, Xi Z. Phys Chem Chem Phys, 2011, 13: 3997

[50] Wendlandt A E, Stahl S S. J Am Chem Soc, 2014, 136: 506

[51] Ghislieri D, Green A P, Pontini M, Willies S C, Rowles I, Frank A, Grogan G, Turner N J. J Am Chem Soc, 2013, 135: 10863

[52] Sonobe T, Oisaki K, Kanai M. Chem Sci, 2012, 3: 3249

[53] Ruži M, Pečavar A, Prudič D, Kralj D, Scriban C, Antonio Z G. Org Process Res Dev, 2012, 16: 1293

[54] Chang M X, Li W, Zhang X M. Angew Chem Int Ed, 2011, 50: 10679

[55] Dong J, Shi X X, Yan J J, Xing J, Zhang Q Xiao S. Eur J Org Chem, 2010: 698

[56] Berhal F, Wu Z, Zhang Z G, Ayad T, Ratovelomanana-Vidal V. Org Lett, 2012, 14: 3308

[57] Romines K R, Freeman G A, Schaller L T, Cowan J R, Gonzales S S, Tidwell J H, Andrews III C W, Stammers D K, Hazen R J, Ferris R G, Short S A, Chan J H, Boone L R. J Med Chem, 2006, 49: 727

[58] Dong J, Shi XX, Xing J, Yan J J. Synth Commun, 2012, 42: 2806

[59] Jin Q R, Jia G Q, Zhang Y M, Li C. Catal Sci Technol, 2014, 4: 464

\section{$P d / C$ 促进的四氢异喹啉高选择性部分脱氢}

\author{
姬 悦 ${ }^{\mathrm{a}}$, 陈木旺 ${ }^{\mathrm{a}}$, 时 䂞 ${ }^{\mathrm{a}, \mathrm{b},}{ }^{*}$, 周永贵 ${ }^{\mathrm{a}, \#}$ \\ a中国科学院大连化学物理研究所, 辽宁大连 116023 \\ ${ }^{\mathrm{b}}$ 大连理工大学精细化工国家重点实验室, 辽宁大连 116024
}


多相催化剂 $\mathrm{Pd} / \mathrm{C}$ 对四氢异喹啉化合物具有催化脱氢活性, 但反应选择性较差, 同时产生完全脱氢的芳构化产物异喹啉. 而 $\mathrm{K}_{3} \mathrm{PO}_{4} \cdot 3 \mathrm{H}_{2} \mathrm{O}$ 修饰的 $\mathrm{Pd} / \mathrm{C}$ 催化剂能有效提高脱氢反应的化学选择性, 在最优条件下可获得最高 $89 \%$ 的分离收率. 这为取代 $3,4-二$ 氢 异喹啉的合成提供了一种简便、高原子经济性和高化学选择性的反应途径. 此外, 该多相催化剂可回收循环使用多次, 且活性和选 择性基本保持不变.

关键词: 钯碳; 部分脱氢; 四氢异喹啉; 亚胺; 脱氢芳构化

收稿日期: 2014-10-01. 接受日期: 2014-11-03. 出版日期: 2015-01-20.

*通讯联系人. 电话: (411)84379220; 电子信箱: shileichem@dicp.ac.cn

通讯联系人. 电话: (411)84379220; 电子信箱: ygzhou@dicp.ac.cn

基金来源：国家自然科学基金(21202162); 大连理工大学精细化工国家重点实验室开放课题基金(KF1110).

本文的英文电子版由Elsevier出版社在ScienceDirect上出版(http://www.sciencedirect.com/science/journal/18722067). 